\title{
Fair Representation and Union Discipline
}

The majoritarian bias of federal labor law makes union oppression of the individual worker possible. The Landrum-Griffin $\mathrm{Act}^{2}$ provides some degree of democracy within the union; but this democracy, while perhaps encouraging fair treatment of minorities, cannot ensure it." Labor law does contain some constraints on union majorities. Section $8(\mathrm{~b})(2)$ of the Taft-Hartley $\mathrm{Act}^{3}$ protects the job rights of the worker, and Section $8(\mathrm{~b})(\mathrm{I})(\mathrm{A})$ of the same Act $^{4}$ has been interpreted to forbid some instances of union discipline. ${ }^{5}$ In addition, the judicially created duty of fair representation has occasionally been invoked to protect workers, especially racial minorities. ${ }^{6}$

Adequate protection of the individual worker must be sought through the interpretation and application of these interrelated provisions. The proper scope of each provision may be determined only by examining the functions and effectiveness of the others, and a narrow interpretation of one duty will require an expansion of another if the Congressional policy of protecting individual workers is to be effectuated. In recent years, the National Labor Relations Board and the courts have struggled to define the scope of Section $8(\mathrm{~b})(1)(\mathrm{A})$. By supporting judicial enforcement of union fines without expanding other protections, courts have allowed the union an additional weapon to coerce individual members.

In 1967, the Supreme Court in NLRB v. Allis-Chalmers ${ }^{7}$ held that judicially enforced fines assessed against members for strikebreaking did not violate $8(\mathrm{~b})(\mathrm{l})(\mathrm{A}) .^{8}$ The following year, the Court held that a

1. 29 U.S.C. $\$ \S 401$ et. seq. (1964). See genterally Summers, American Legistation far Union Democracy, 25 MoD. L. REv. 273 (1962).

2. [I] is well to be clear that while governmental regulation of internal union affairs seeks, among other things, to achieve fair representation by providing a climate within the union conducive to full membership control and hostile to topdown rule, it cannot, no matter how successful it may be, protect the minority from the majority'. And accordingly, regulation of internal affairs cannot be thought of as an alteriative to governmental review of union collective bargaining decisions.

H. Wellington, labor and the Legal Process 186 (1968).

3. 29 U.S.C. $\$ 158(\mathrm{~b})(2)$ (1964). See also Radio Oficers Union v. NLRB, 3.17 U.S. 17 (1954).

4. 29 U.S.C. \& $158(\mathrm{~b})(\mathrm{l})(\mathrm{A})(1964)$.

5. See note 9 infra.

6. For an extended discussion of the duty of fair representation, see pp. 784.35 infra.

7. 388 U.S. 175 (1967).

8. The National Labor Relations Board upheld the trial examiner who recommended that the complaint by Allis-Chalmers be dismissed. 149 NLRB 67 (1964). The Board considered that the proviso to $8(\mathrm{~b})(\mathrm{I})(\mathrm{A})$ protected such union enforcement of fincs. 14! NLRB at 69. The Court of Appeals initially upheld the decision of the Board, but upon 
union violated $8(\mathrm{~b})(\mathrm{I})(\mathrm{A})$ by expelling a union member who, without having exhausted internal union appeals, had filed an unfair labor practice complaint against the union. ${ }^{\circ}$ And most recently, in Scofield $v$. $N L R B,{ }^{10}$ the Supreme Court found no violation when a union secured judicial enforcement of fines upon members who demanded payment for production exceeding the norms embodied in union rules.

Although $8(\mathrm{~b})(1)(\mathrm{A})$ was enacted primarily to eliminate coercive tactics employed by unions during organizational campaigns, ${ }^{11}$ the section cannot be limited to such practices. Section $8(b)(1)(A)$ states:

a rehearing en banc held that a literal interpretation of $8(b)(1)(A)$ required a finding of an unfair labor practice. Allis-Chalmers v. NLRB, 358 F2d 656 (7th Cir. 1966).

Numerous Notes have analyzed the Allis-Chalmers decision. One of these Notes has briefly discussed the possible relationship between union discipline and fair representation. Note, Labor Policy: Judicial Enforcement of Fines after Allis-Chalmers, 53 Consinc L.Q. 1094, 1097, 1107 (1967).

9. NLRB v. Industrial Union of Marine \& Shipworkers, 391 U.S. 418 (1969).

The approach of the Supreme Court in Marine $\&$ Shipworliers anticipated the dunl approach articulated in Scofield for testing the validity of union discipline. Rules protecting legitimate union interests are allowed, $391 \mathrm{USS}$. at 424; and so Iong as no general federal labor policy is violated, union discipline does not violate $8(b)(1)(A)$, 391 US. at 425. See p. 743 infra. In Marine of Shipworkers, the discipline involved failed to meet either of these two tests. See Etelson \& Smith, Union Discipline under the LandrumGriffin Act, 82 HARV. L. REv. 727 (1969) for a discussion of this case.

Both expulsion, as in Marine i Shipworkers, and fines were disallowed where unfair labor practice charges were filed by a member without exhausting internal appeals. Operating Engineers Local 138 (Charles S. Skura), 148 NLRB 679 (196-1). See also Van Camp Sea Food Co., Inc. 159 NLRB 843 (1966), aff'd. 396 F.2d 955 (9th Cir. 1968), cert. denied, sub. nom. Cannery Workers Union of the Pacific v. NLRB, 393 U.S. 1025 (1969); H.B. Roberts, 148 NLRB 674 (1964), enforcing 350 F.2d 427 (D.C. Cir. 1965).

In Pittsburgh Des Moines Steel Company (United Steelworkers of America, Loal No. 4028), 154 NLRB 692 (1965), pet. den. Price v. NLRB, 373 F2d 413 (9th Cir. 1967), cert. denied, 392 US. 904 (1968), and Tawas Tube Products, Inc., I5I NLRB 40 (1965), the Board allowed the unions to defend themselves by expelling or suspending members who filed decertification petitions. In Molders tocal 125, 178 NLRB No. 25 (1969), the Board held that fining a member for filing for decertifiation becomes punitive and violates $8(\mathrm{~b})(\mathrm{l})(\mathrm{A})$.

The Board has disabused itself of early notions that all discipline vas protected by the proviso to $8(\mathrm{~b})(\mathrm{I})(\mathrm{A})$ and seems to recognize that there are diftering degrees of coercion and restraint inherent in fines and expulsion. The Board in Tawas Tube (noted with approval in Molders) decided that "attempt[s] to repudiate the union demonstrates that Ioss of membership vias of no significance to them; consequently then expulsion from the union could hardly be an effective deterrent against resorting to the Board." 151 NLRB at 49.

It should be recognized, however, that workers filing a petition for decertification may do so for union political reasons such as wresting concessions from a dominant majority rather than a desire to be rid of the union entirely.

10. 394 U.S. 423 (1969).

11. See the discussion of the legislative history by Justice Brennan in NLRB v. AllisChalmers, 388 U.S. at 184-91. See also Comment, Labor Law: Union Fining as an Unfair Labor Practice under Section $\delta(b)(1)(A), 1966$ DUnE L.J. 717, 719 \& nn.11 \& 12, and caces cited therein, especially Perry Norvell Co., 80 NLRB 225 (1948). In Perry Norvell, the Board declared that in "section 8(b)(1)(A), Congress sought to fix the rules of the game, to insure that strikes and other organizational activities of emplojees were conducted peaceably by persuasion and propaganda and not by physical force, or threats of force, or of economic reprisal." 80 NLRB at 239. For discussion of the devclopment of $8(\mathrm{~b})(\mathrm{I})(\mathrm{A})$ and its application, see Comment, 1966 DUkE L.J., supra. 
It shall be an unfair labor practice for a labor organization or its agents to restrain or coerce employees in the exercise of the rights guaranteed in section 7: Provided, that this paragraph shall not impair the right of a labor organization to prescribe its own rules with respect to the acquisition or retention of membership therein..$^{12}$

The rights protected by Section 7 are expansive and go beyond mere organizing activities:

Employees shall have the right to self-organization, to form, join, or assist labor organizations, to bargain collectively through representatives of their own choosing, and to engage in other concerted activities for the purpose of collective bargaining or other mutual aid or protection, and shall also have the right to refrain from any or all of such activities except to the extent that such right may be affected by agreement requiring membership in a labor union as a condition of employment as authorized in section $8(\mathrm{a})(3) \cdot{ }^{13}$

In addition, the very purpose of enacting union unfair labor practices - to impose controls on unions comparable to those placed on employers-compels a wider reading of the section. ${ }^{14}$ Congress was con* cerned with the ability of the individual worker to exercise free choice not merely at the organizing stage but also following successful orga. nization of the union.

Because the language and legislative history of $8(\mathrm{~b})(1)(\mathrm{A})$ do little to further an understanding of its scope, ${ }^{15}$ courts must look to the impact which $8(\mathrm{~b})(1)(\mathrm{A})$ may have on the interests of the union and employees..$^{16} A$ literal reading of the words "restrain or coerce" might

\footnotetext{
12. 29 U.S.C. $\S 158(\mathrm{~b})(1)(\mathrm{A})(1964)$.

13. 29 U.S.C. $\S 157$ (1964).

14. To a large degree, $8(\mathrm{~b})(1)$ (A) was enacted to parallel the sanctions imposed on the employer in $8(\mathrm{a})(1)$. From a pro-union bias inherent in the Wagner Act, the Taft-Hartley Act shifted to a far more neutral role in the ordering of labor relations. See Cox, Some Aspects of the Labor Management Relations Act, 1947, 61 HARv. L. REv. 1, 44 (1947).

15. Because $8(\mathrm{~b})(1)(\mathrm{A})$ was introduced as a Senate floor amendment, its sparse Ichis. lative history provides little insight into the intent of its framers. For a general discussion of the legislative history see Comment, $s(b)(1 \times A)$ Limitation Upon the Right of a Union to Fine its Members, 115 U. PA. L. Rev. 47, 52-59 (1966). The legislative history ecems inconclusive on the question whether judicially enforced fines are prohibited by $8(b)(1)(A)$. The Pennsylvania Law Review apparently believed otherwise: "The words of the scction as well as its purpose as revealed by the legislative history lead to the conclusion that union fines which the member reasonably belleves might be enforced thraugh logal procecdings fall within the prohibition of section $8(\mathrm{~b})(1)(\mathrm{A}) . "$ Id. 59.

16. The Board and courts have for many years balanced the interests of the employer and employees in determining the scope of 8(a)(1). Compare Republic Aviation V. NLRB, 324 U.S. 793 (1945), with NLRB v. Babcock \& Wilcox Co., 851 U.S. 105 (1956), For an analysis of 8(a)(1) and 8(a)(3), see Oberer, The Scienter Factors in Section $S(a)(1)$ and (3) of the Labor Act: Of Balancing, Hostile Motive, Dogs and Tails, 52 Connetx L.Q. 491 (1967).
} 
well severely impair a union's ability both to organize and to bargain effectively. ${ }^{17}$ The union has a clearly recognized stake in maintaining its effectiveness as a bargaining agent. Indeed, in Allis-Chalmers the Supreme Court, while citing several factors, ${ }^{18}$ seemed to justify its finding that $8(\mathrm{~b})(\mathrm{l})(\mathrm{A})$ does not prohibit judicial enforcement of union fines on the necessity of the union maintaining itself as a bargaining agent. ${ }^{19}$

The stronger the united front it presents to the employer, the more effective the union will be in gaining maximum benefits for distribution to the collective bargaining unit..0 The division of benefits within that unit, however, will not, because of the inherent imperfections of collective bargaining, reflect perfectly the productivity of individual workers. Nor does collective bargaining attempt this task. Some leveling among workers is often intended. ${ }^{21}$ But because majority rule generally creates and ratifies policy, ${ }^{22}$ minority workers may be forced

17. See Summers, Disciplinary Powers of Unions, 3 INo. \&. LAB. REL. REv. 483, 489 (1950).

18. The court placed some emphasis on the intent of the proviso to $8(\mathrm{~b})(\mathrm{I})(\mathrm{A})$, 388 US. at 191-92, and on a very hazy legislative history, 388 U.S. at 184-91. Sec note I5 supra. Finally, is cited the legal fiction of the contract theory governing relations betricen unions and members. 388 U.S. at 182-83. The contract theory is admittedly abstract, especially in the context of a unionshop. 1966 DukE L.J., supra note 11, at 736. See also Summers, Legal Limitation in Union Discipline, 64 HARv. L. REv. 10.9, 1055.56 (1951).

19. Integral to this federal policy has been the power in the chosen union to protect

against erosion its status under that policy through reasonable discipline of a mem-

ber who violates rules and regulations governing membership.

388 U.S. at 181 .

Stressing the importance of maintaining the union as the exclusive bargaining agent implies that a worker should not be able to question either the strategy or most of the objectives of a strike. However, the duty of fair representation recognizes the individunl's right to resist unfair bargains. As a result this Note is primarily concerned with protecting the individual's ability to refuse to support strikes for unfair objectives, and not with protecting dissent about tactics or other considerations. For a discussion of what the Board considers as inappropriate strike objectives, see note 40 infra.

20. See Summers, supra note 17, at 495, cited by Justice Brennan in Allis-Chalmers, 388 U.S. at 181-82 n.8.

21. See G. Bloom \& H. Northrop, Economincs of Lador ReLations 383 (5th ed. 196j):

In the thirties and forties, when the advent of industrial unionism first made its impact felt in the wage structure, there was a strong trend for larger percentage wage adjustments for the lower paid emplojees. As a result, there was a definite narrowing of occupational differentials. By the early fifties a slowing of this narrowing process was observable, and in recent years, there has been cvidence of the maintenance of reasonably stable differentials. This has been partly attributable to an increasing tendency to grant special increases for skilled workers.

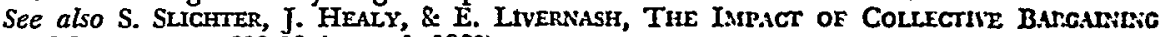
on MaNagement 602-03 (rev. ed. 1960).

22. See the discussion of $J I$. Case, p. 743 infra and in Wellington, supra note 2, at 130 . "[T] he majority rule concept is today unquestionably at the center of our federal labor policy." Wellington, Union Democracy and Fair Representation, 67 YALE I.J. 1327, 1339 (1958).

Of course, majority rule often must work through the imperfect mechanism of elected union leaders. Title IV of Landrum-Griffin regulates elections of union officials. Professor Summers noted that the "statute is built on the basic premise that control of the union belongs to the members. The purpose of this Title (IV) is to assure that union 
to subsidize other workers unreasonably unless the Board or courts somehow restrain unfair distributions of benefits.

\section{Constraints on Majority Oppression}

One possible safeguard against unfair majoritarian bargains-the duty of fair representation-has developed from the Supreme Court's decision in Steele v. Louisuille of N.R. Co. ${ }^{23}$ In Steele, the Court, sensing that the majority of workers represented by a union could easily oppress an unprotected minority, declared: "The fair interpretation is that the organization chosen to represent a craft is to represent all its members, the majority as well as the minority, and it is to act for and not against those whom it represents."24

The Steele decision struck down bargaining policy based on racial discrimination, and although that result cannot be faulted, the decision relied on a standard of fair representation which provides little further protection to the individual union member. ${ }^{25}$ The courts have hesitated to require that a union's bargaining decisions meet a more sensitive standard than reasonableness, rationality, and absence of arbitrariness, ${ }^{26}$ perhaps, as has been suggested, because of their un-

officers, whose day-by-day decisions are the building blocks of union policy, sliall be responsive to the will of the members." Summers, American Legislation for Union Democracy, 25 MoD. L. REv. 273, 290 (1962). See generally Beaird, Union Officer Election Provision of the LMRDA of 1959, 51 VA. L. REV. 1306 (1965).

23. 323 U.S. 192 (1944).

24. Id. at 202. Although articulated within the context of the Railway Labor Act, the duty of fair representation has been applied in cases arising under the National Labor Relations Act. Syres v. Oilworkers Local 23, 350 U.S. 892 (1955) (per curiam). It has been extended to administration of the contract as well as its formation, sce Conlcy $v$. Gibson, 355 U.S. 41 (1957).

For a general examination of the doctrine of fair representation see Cox, The Duty of Fair Representation, 2 VIL. L. REv. 151 (1957); Wellington, Union Democracy and Fair Representation Federal Responsibility in a Federal System, 67 YALE L.J. 1927 (1958); and more recently, Wellington stppra note 2 , at 145.84 .

Whether the breach of the duty of fair representation creates an unfair labor practice remains unclear. Since the 1962 Board decision of Miranda Fucl Co., Inc., 140 NLRB 181, enforcement denied, 326 F.2d 172 (2d Cir. 1963), the Board has maintained that tho duty of fair representation could be derived from $8(b)(1)(\Lambda)$ as well as $8(b)(2)$ and later 8(b)(3). In Rubber Workers Local 12 v. NLRB, 368 F.2d 12 (5th Cir. 1966), cert. denied, 389 U.S. 837 (1967), the Court of Appeals held that the Board was entrustcd with cllforcement of the duty of fair representation in $8(\mathrm{~b})(1)(\mathrm{A})$, but refused to rule on whether a breach of the duty constituted an unfair labor practice in violation of $8(\mathrm{~b})(2)$ and 8(b)(3). In Vaca v. Sipes, 386 U.S. 171, 186 (1967), the Supreme Court scemed to Imply that the Board enjoyed concurrent jurisdiction over the duty of fair representation.

25. See Wellington, supra note 2 , at 145.53 and 155.63 for a full discussion of the standards developed by the courts.

26. The equal protection clause was employed in Steele as an analogy, not as a constitutional requirement. ... Nothing in the union's structure and function suggests

that it should be held to a less exacting standard of conduct in its legislative atctivities (prospectively establishing the terms and conditions of employment) than state or federal legislatures. Indeed, as we shall see, a higher standard is called for.

Wellington, supra note 2, at $148-49$. 
familiarity with labor relations. ${ }^{27}$ The Supreme Court in Ford Motor Go. v. Huffman ${ }^{28}$ did apply a good faith and honesty of purpose test, ${ }^{29}$ while relying as well on federal statutory policy, ${ }^{30}$ to support the union's granting seniority to returning servicemen not previously employed by the company. But neither good faith nor statutory policy will often be reliable guides in collective bargaining situations. Bad faith can be easily disguised, and federal policy of such informing magnitude is likely to occur infrequently. ${ }^{31}$ In effect, the duty of fair representation has provided little substantive protection, except against racial discrimination, to members either in the negotiation of contracts ${ }^{32}$ or in their administration. ${ }^{33}$

A sensitive duty of fair representation would help to eliminate unjust bargains. ${ }^{34}$ But limitations on the ability of the union to discipline

27. Id. at 162-63, 165-66.

28. 345 U.S. 390 (1953).

29. Id. at 338 .

30. Id. at $340-41$.

31. Professor Wellington suggests that public policy could be derived from Title VII of the Givil Rights Act of 1964, the LMRDA, and other clear statements. Yvellington, supra note 2, at 166. For a treatment of the duty of fair representation and Title VII of the Civil Rights Act, see Sherman, Union's Duly of Fair Representation and the Civil Rights Act of 1964, 49 MINN. L. REv. 771 (1965).

32. As Judge Thornberry noted in Rubber Workers Loal 12 v. NLRB, 363 F2d 12 (5th Cir. 1966), the courts have viewed union action with a "heavy regularity of presumption." 368 F.2d 23 n.22.

Truck Drivers and Helpers Local 568 v. NLRB, 379 F.2d 137 (D.C. Cir. 1967) is the type of case which presents the adjudicator, whether the Board or a court, with admittedly difficult decisions of allocating seniority (and in effect jobs or unemplojment) between members of merging companies. The Board and court both found that the union bresched its duty of fair representation when it announced, prior to a certification clection for the merged unit, that no one from the dominant majority would lose his job. As one commentator surmised:

On the surface, the decision not only reiterated the Supreme Court's faith in the duty of fair representation, but also represented a departure from a policy of judicial restraint. A closer look reveals, hovever, that instead of strengthening an individual's protection against the union's bad faith, the decision merely underscored how fecble the protection is. Essentially, the court of appeals' finding of a breach of the union's duty of fair representation was a response to the blatant display of bad faith on the part of the union.

Comment, Seniority and Business Mergers: The Union's Duty of Fair Representation, 35 U. CEI. L. REv. 342 (1968).

For another recent example of the court's reluctance to intervene in the negotiation of contracts, see Gainey v. Brotherhood of Railway \& Steamship Clerks, 275 F. Supp. 292 (E.D. Pa. 1967), affd., 406 F.2d 744 (1968), cert. denied, 394 U.S. 998 (I969). In the Gainey decision, the court applied the oft utilized "hostile discrimination" test derived from Steele, and cited with approval the Huffman case which recognized that "compromises on a temporary basis, with a view to long-range advantages, are natural incidents of ncgotiation." Yet the question which must be answered is who is acrificing what for whoin. See also Thomson v. Stage Emplojees \& Moving Picture Machine Operator, 232 C.A.2d 446, 42 Cal. Rptr. 785, cert. denied sub. nom. Thomson v. Carman, 382 US. $9: 0$ (1965) (one class of workers was forced to subsidize a changeover in the type of hiring).

33. See Wellington, supra note 2, at 183; Lenis, Fair Representation in Griecance Administration, 1967 Suprese Courr REVIEw 81, 107.

34 . While the duty of fair representation has been viewed as a duty to divide the benefits negotiated in free collective bargaining in an equitable manner among union 
its dissatisfied members may achieve similar results. The less a union can use discipline to stifle dissent, the more a disaffected minority may force the majority, which desires to present a united front, to bargain fairly. ${ }^{35}$ But even if the union has little disciplinary power, there might still exist situations where the majority of workers possesses sufficient economic clout to attain a bargain which clearly benefits them at the expense of a minority. Thus, the duty of fair representation-if articulated forcefully-may assure fair bargains in a broader range of sit. uations than would restrictions on the union's ability to discipline members who fail to support union policy. But this broader protection will come at a price many may be unwilling to pay-infringement upon free collective bargaining. ${ }^{36}$ It may be less costly to construe $8(\mathrm{~b})(1)(\mathrm{A})$ substantially to restrict union discipline and allow the minority and majority to distribute benefits to the members by mutual adjustment and compromise within the union. ${ }^{37}$ In any event, it should be recog-

workers, it is not clear that forcing a union to bargain with a view to the just distribution of benefits may not actually result in a higher level of benefits accruing to the unit. Certainly, the employer has sufficient information to recognize when a certain group of workers is not receiving its "fair" share. In this situation, it would scem possible that ho would request a side payment (i.e., a lower overall cost for the bargaining patckagc) in order to agree to aid the majority at the expense of the minority. Thus, the worker's being discriminated against would receive less benefits because some of their benefits are received by the majority and some by the employer. But cf. discussion why $8(\mathrm{~b})(8)$ is an inappropriate way to lodge the duty of fair representation in the Board. Wcllington, supra note 2 , at 68 .

35. John Dunlop notes that "[o]ne of the major activities of collective bargaining involves the determination of priorities within each side in the bargaining process." Dunlop, The Social Utility of Collective Bargaining, in Chaldenoes to Coldective Bargaining 168, 173 (L. Ulman ed. 1967).

And to "an increasing extent, the union function involves a mediation between conflicting interests of its membership." Id. But the ability to utilize judicially enforced fincs may very well short-circuit the mediation process.

Professors Summers and Wellington seem to suggest that the more responsive union leaders are to its members, and the more viable the union's internal political processes, the more likely will the majority trade off certain policies to gain minority support. C. Summer \& H. Wellington, Cases in Labor LAw 1139 (1968). There are, of course, limitations in this trading-off process. The smaller the percentage of workers and the less their ability to undercut a strike by the remaining workers, the less likely will a majority curry favor with them. In addition, no matter how large the minority is, if really stable coalitions of interest exist, the push of the Landrum-Griffin Act for dcm. ocratic rule may make union leaders responsive only to the dominant majority.

36. Professor Wellington, who has argued for a strengthened duty of fair represcnta. tion, recognized these possibilities but considers the cost worth it.

In earlier chapters, $I$ have argued against such interference by government with the statutory goal of freedom of contract. My earlier arguments, however, had a component that here is absent. In the arbitration, no-strike, and duty to bargain situations, governmental interference with freedom of contract is virtually without purpose. The stated purpose, industrial peace, is illusory. But governmental interference with freedom of contract to achieve fair representation is purposeful. To protect the individual, freedom of contract must yield; but if the standards that are developed for this purpose are drawn from an industrial context, the effect on collectlve bargaining need not be too hurtful.

Wellington, supra note 2 , at $163-64$.

37. It will be less costly only in the sense that the bargaining process will not be 
nized that the duty of fair representation and $8(\mathrm{~b})(\mathrm{I})(\mathrm{A})$ restrictions on union discipline may protect similar minority interests.

\section{The Holding in NLRB v. Allis-Chalmers}

The Court in Allis-Chalmers could have chosen one of two alternative routes-a per se rule or an ad hoc approach ${ }^{38}$-in deciding whether a judicially enforced fine imposed when a member crosses a picket line constitutes restraint or coercion within the meaning of $8(\mathrm{~b})(1)(\mathrm{A})$. A per se rule, while sacrificing flexibility, avoids the uncertainty and expense of assessing the amount of coercion in each situation. But whether articulating a per se or ad hoc rule, the courts must rely on some benchmark of permissible restraint against which to compare the impact of judicially enforced fines. To a certain extent Justice Brennan for the Court and Justice Black for the dissent found that benchmark in the degree of coercion implicit in expulsion from union membership. The rationale for this point of reference is found in the proviso to $8(b)(1)(A)$, which speaks of the "right of a labor organization to prescribe its own rules with respect to the acquisition or retention of membership therein," 39 and which might well be construed to insulate expulsion from the proscriptions of $8(\mathrm{~b})(1)(\mathrm{A}) .^{* 0}$ In addition, unions had commonly expelled members both prior to and after the passage of Taft-Hartley. ${ }^{41}$

Whether the quantum of coercion exerted by a judicially enforced fine exceeds that of expulsion from the union depends greatly upon the individual's willingness to sacrifice cash for the benefits of unionism. Social ostracism resulting from expulsion may not disturb many union members, particularly those members who have dissented from majority policy. In addition, as long as the worker pays his dues

disrupted. Of course, where an identifiable minority lacks the cohesiveness or pover to force concessions, then the minority will suffer, and this is a cost which cannot be discounted.

38. For a discussion of per se and ad hoc rules, see Note, Civil Disabilities and the First Amendment, 78 YALE L.J. 842, $851-53$ (1969).

39. See p. 732 supra.

40. The Board has altered its position as to whether fines in strike ases are insulated by the proviso or by $8(\mathrm{~b})(1)(\mathrm{A})$ itself. In District 50, Local 12419 (National Grinding Wheel Co.), 176 NLRB No. 89, 71 LRRM 1311 (1969), the Board held that a fine could not be assessed against a member for crossing a picket line of a sister local union when the member's union had a no-strike clause in its contract. The Board noted that such a rule even if "part of a union's legitimate internal affairs . . nevertheless orerreaches the bounds of legitimacy." 71 LRRM 1315. Accord, Bricklayer S: Masons Local No. 2, 165 NLRB No. 26 (1967) (a secondary boycott situation).

41. While it is true that fining antedated the Taft-Hartley $A c t$, only recently has it reached such importance. See Comment, 1966 Durk L.J., supra note 11, at 718. 
in a union, agency, or maintenance-of-membership shop, the union cannot affect his job rights. ${ }^{42}$ Thus the member, by refusing to pay his fine, will at the most lose his membership rights, but will retain the benefits associated with the collective agreement. But if expelled, the worker may lose or be unable to replace union pension rights, insurance and related items which in certain cases may exceed the value of the fine. ${ }^{43}$ The Allis-Chalmers Court is wrong when it declares that, as a general proposition, expulsion from a strong union has a greater impact on a union member than court-enforced fines. ${ }^{44}$ The relation. ship of membership benefits to the size of the fine-not to the strength of the union-determines whether judicially enforced fines are more coercive than expulsion. Both the Court and the dissent selected largely per se rules, ${ }^{45}$ thereby avoiding the necessity of examining the relation of the fine to union benefits. Justice Brennan for the Court postulated that judicially enforced fines in the context of a lawful strike are not sufficiently coercive to warrant an $8(\mathrm{~b})(1)(\mathrm{A})$ unfair labor practice. Justice Black for the dissent seemed to find the quantum of coercion in the fine itself, ${ }^{40}$ even without the factor of judicial enforcement, a violation of $8(\mathrm{~b})(\mathrm{l})(\mathrm{A})$.

42. It "is permissible to condition employment upon membership, but membership, insofar as it has significance to employment rights may in turn be conditioncd upon only payment of fees and dues." NLRB v. General Motors, 373 U.S. 734, 742 (1968).

See Radio Officers Union v. NLRB, 347 U.S. 17 (1954).

Thus $\S \S 8(\mathrm{a})(3)$ and $8(\mathrm{~b})(2)$ were designed to allow employecs to frecly cxercise their right to join unions, be good, bad or indifferent members, or abstain from joining any union without imperiling their livelihood. The only limitation Congress has chosen to impose on this right is specified in the proviso to $\& 8(\mathrm{a})(3)$. . . . Congness intended to prevent utilization of union security agreements for any purpose other than to compel payment of union dues and fees.

Id. at $40-41$.

43. [E]xclusion from the union may deprive the individual of various social bencfits provided by the organization. The importance of this depends on the particular benefits offered and their practical availability elsewhere. For cxample, pensions or medical insurance may be difficult to obtain through other chaninels, and strike benefits are provided only by the union. A member who is expelled may, furthermorc, be unable to replace life insurance cancelled by his expulsion.

Summers, International Relations: General Report, 18 RuTGERS L. REv, 286, 263 (1961). See NLRB v. Amalgamated Local 286, 222 F.2d 95, 98 (7th Cir. 1955), which held that the dropping of insurance coverage was an incident of membership not prohibited by 8(b)(I)(A), and that coverage was not a condition of employment despite the fact that the employer really paid for the insurance. Of course, where employer contributions arc involved in union-administered health and welfare benefits, then curtailing bencfits for non-members would violate $8(\mathrm{a})(3)$ and $8(\mathrm{~b})(2)$ as well as $8(\mathrm{~b})(1)(A)$. Local 198, Opcrating Engineers v. NLRB, 321 F.2d 130 (2d Cir. 1963); NLRB v. Local 815, Teamsters, 290 F.2d 99 (2d Cir. 1961); Indiana Gas \& Chemical Works, 120 NLRB 1488 (1961). Sec also Coinment, 115 U. PA. L. REv., supra note 15, at 73.

44. 388 U.S. at 183-84.

45. The Board has begun to inquire into the size of the fine to determine whetlicr an $8(\mathrm{~b})(1)(\mathrm{A})$ violation has been committed-certainly a departure from a per se approach. See the cases cited in Silard, Labor Board Regulation of Union Discipline Afier Allis. Chalmers, Marine Workers and Scofield, 38 GEo. WASH. L. REv, 189, 194 \& n.26 (1969).

46. Id. at 202-03. 
While neither per se rule is completely satisfactory, the Court's rule is particularly troublesome because it grants the union, in many instances, additional coercive power with which to oppress minority workers. Although the Allis-Chalmers majority did not feel compelled to examine the extent of the protection afforded the worker by the duty of fair representation, they noted that it was fashioned " 'to prevent arbitrary conduct," "47 thereby suggesting that the Court viewed the duty as adequate to protect union minorities. But, as noted earlier, the duty of fair representation offers little substantive protection. ${ }^{48}$

The Court in Allis-Ghalmers may have assumed that majority oppression is rare. It is probably true that most strikes seek to benefit all workers and not just the majority; but without any standard to test the substance of the bargain, it is impossible to say how many are actually "fair." Often the individual worker will break a strike because he feels that holding out for additional gains, is just not worth the cost, and not because he feels that the union is treating his minority interest unfairly. Yet experience even with a relatively responsible union, the United Auto Workers, suggests that certain bargains have been biased toward the interests of the dominant majority..$^{10}$ And it may be that these instances of majority biased bargains are of sufficient importance to justify rejection of Justice Brennan's approach. While it may not be disturbing if the majority of workers gain extra benefits on their own, it should be disturbing if the majority forces a minority to subsidize its efforts to obtain such a bargain.

On the other hand, it must be clearly recognized that Justice Black's approach of barring judicial enforcement of fines in a strike situation would also entail a cost. Where the union is dispensing benefits to all members fairly, the individual union member who is able to defy union policy may be able to obtain the benefits of his strikebreaking as well as those of the bargain eventually struck by his fellow workers. If other provisions of federal labor law protected the minority worker

47. Id. at 181. The Court cited Vaca v. Sipes, 386 U.S. 171, 182 (1967). Justice Brennan did cite approvingly the section of the Steele opinion which compared a union to a legislative body, and the Huffman opinion section which stressed the "wide range of reasonableness" allowed a union. 388 US. at 180. See note 26 supra for criticism of such an analogy.

48. See pp. 734-35 supra.

49. The skilled trade workers' revolt in the United Auto Workers pointed up the narrowing differentials between the skilled and production vorkers in the auto industry. For a discussion of the varying bargaining practices of the United Auto Workers and United Steel Workers, see L. REYNolds \& C. TAFT, THE Evolution of WAGE STnuctune 324-25 (1956). The United Steel Workers until the mid-fifties attempted to and did rather successfully maintain the historical differential between skilled and unskilled workers in the industry. Id. See also A. ReEs, The Econosics of Trade Unions 64 (1969). 
without sacrificing bargaining power, then the Court's limitation on the scope of $8(\mathrm{~b})(\mathrm{I})(\mathrm{A})$ would not be disturbing. The major protective provisions ${ }^{50}$ other than $8(\mathrm{~b})(1)(\mathrm{A})$ and the duty of fair representation reside in Sections $8(a)(3)$ and $8(b)(2)$ of the Taft-Hartley Act ${ }^{\text {tit }}$ and Section 101(a)(5) of the Landrum-Griffin Act. ${ }^{52}$ Sections $8(a)(3)$ and 8(b)(2) prohibit an employer from discriminating, and a union from causing an employer to discriminate, "in regard to hire or tenure of employment or any term or condition of employment to encourage or discourage membership in any labor organization," while Section 101 (a)(5) assures procedural due process-including the serving of specific charges, allowing a reasonable time for the preparation of the defense, and affording full and fair hearing. But these provisions do little to protect against majoritarian oppression. Except for discrimination designed to encourage union membership, ${ }^{63} 8(b)(2)$ does not regulate job

50. An additional possible protection for identifiable minority workers lies in their ability to petition for craft severance. Mallinckrodt Chemical Works, 162 NLRB 387 (1966), may deter severance elections because "the interests of all cmployees in continuing to bargain together in order to maintain their collective strength, as well as the public interest and the interests of the employer and the plant union in maintaining overtill plant stability in labor relations and uninterrupted operation of integrated industrlal or commercial facilities, may favor adherence to the establishcd patterns of bargainlny." 162 NLRB at 392. See Note, Craft Severance: NLRB's New Approtral, 1967 IND. L.J. 5FH, for a discussion of the doctrine.

Again, conditioning the availability of petitions according to the interests of the cm. ployees in maintaining bargaining strength makes sense only as long as the duty of fair representation operates to deter unfair bargains.

51. Section $8(a)(3)$ provides in part:

$[\mathrm{N}]$ o employer shall justify any discrimination against an employee for nonmembership in a labor organization ... (b) if he has reasonable grounds for believing tlit membership was denied or terminated for reasons other than the fallure of the chn. ployee to tender the periodic dues and the initiation uniformly requircd as a condition of acquiring or retaining membership.

29 U.S.C. $\$ 158(\mathrm{a})(3)(1964)$.

Section $8(\mathrm{~b})(2)$ provides:

It shall be an unfair labor practice for a labor organization or its agents to cause or attempt to cause an employer to discriminate against an employce in violation of subsection (a)(3) or to discriminate against an employee with respect to whom mem* bership in such organization has been denied or terminated on some ground other than his failure to tender the periodic dues and the initiation fees uniformly required as a condition of acquiring or retaining membership.

29 U.S.G. \$158(b)(2) (1964).

52. 29 U.S.C. $\$ 411(a)(5)$ (1964).

53. In sum, the sections $[8(a)(3)$ and $8(b)(2)]$, as they relate to the encouragement of union membership, mean that in the negotiation and administration of the collec. tive agrecment, the union cannot legally bargain to the disadvantage of non-union employees. For bargaining purposes, nonmembers must be treated the same as mem. bers. Moreover, discrimination may not be practiced against $\mathfrak{a}$ bad union menber in order to encourage him to follow the union rules; and this is so whether or not there is a union shop agreement.

Wellington, stlpra note 2 , at 134 . It can be seen that the duty of fair represcitution provides for more significant protection than $8(a)(3)$ and $8(b)(2)$. 
benefits. And a hearing may be perfectly fair in a procedural sense ${ }^{54}$ but still result in an oppressive fine with subsequent enforcement. ${ }^{55}$

Scofield v. NLRB does suggest that a non-member may freely disagree with union policy. ${ }^{56}$ Thus, the dissident worker could protect himself from fining by refraining from joining or by resigning from the union. But to avoid the fine and subsequent enforcement, resignation would seemingly need to precede the implementation of and disagreement with the policy. ${ }^{67}$ Whether most workers are sufficiently clairvoyant to anticipate such discipline seems highly unlikely. In addition, where union, maintenance-of-membership, or agency shops exist, the dues-payer who is forced to contribute to the financial perpetuation of the union may believe it worthwhile to attempt to alter union policies through the exercise of his political rights within the union."s Requiring resignation to avoid liability for fines would defeat the purposes for which Landrum-Griffin was enacted-a more democratic environment within the union ${ }^{59}$-by creating a totally unrepresented and dissident minority. ${ }^{60}$

54. Professor Summers notes that $\S 101$ (a)5 "[e]xoept for requiring that the clarges be written and specific ... adds nothing to the standard of fair procedure long enforced by the courts. The statute leaves unsolved the problem which has plagued the courts-the built-in bias in union tribunals." Summers, American Legislation for Union Democrac\%" 25 MOD. L. REv. 273, 288 (1962).

And as recent commentators to the LMRDA note:

Another significant source of problems is the line between union discipline and

union policy, the latter still being immune, for sound reasons, from judicial inter-

ference. When union action is taken or withheld as a matter of "policy," the fact that

it results in disadvantage to one or more of the members does not make . . [it] discipline.

Etelson \& Smith, Union Discipline under the Landrum-Grifin Act, 82 Hanv. L. REv. 727, 731-32 (1969).

55. Although the Allis-Chalmers case seems to lead a court to enforce fines, a state court still has discretion to decide whether to allow enforcement cien when no $8(\mathrm{~b})(\mathrm{l})(\mathrm{A})$ violation is found. In Local 248, UAW v. Natzke, 36 Wis. 2d 237, 251, 153 N.W.2d 602 (1967), the court held that a fine was "a binding obligation in the form of a debt ... subject to collection by court action." See also Local 756, UAW v. Woychik, 5 TVis. 2d 528, 93 N.W.2d 336 (1958). But see Local No. 188, United Glass Workers v. Scitz, 65 YYash. 2d 640, 399 P.2d 74 (1965); Local 629, Retail Clerks v. Christiansen, 67 Wash, 2d 29, 406 P.2d 327 (1965). See Note, Court Enforcement of Union Fines, 25 TWAst. \& LEE L. REv. 273 (1968).

56. 394 U.S. at 435 . He will still be forced to contribute his dues if required by $a$ union-security arrangement, but because he fails to participate in the decisions of the union, he will be free from the consequences of union policy.

57. As long as a contractual theory of union membership is retrined it must be assumed that $a$ member will not be able to avoid fines by violating union policy and resigning subsequently. Thus, if a member votes to strike and then learns of the "unfair" bargains being negotiated, he will probably not be able to avoid liability by resigning.

58. The political rights guaranteed under the LMRDA are elaborated in Title I (Bill of Rights). See \$ 101(a)l (Equal Rights) and \$ 101(a)(2) (Freedom of Speech and Assembly).

59. See Summers, supra note 54, at 276-77 (1962).

60. The inability of the worker to express his views within the union and to cast his ballot for the type of leaders he deserves will reduce the likelihood of "just" policies being implemented. But even the most democratic union environment will not guarantee "just" policies. See note 2 supra. 


\section{A Suggested Approach}

An increase in majority power through judicial enforcement of fines can be justified if the Supreme Court sanctions a strengthened duty of fair representation, probably lodging enforcement of the duty in the Board.61 Merely recognizing such a duty might deter many unfair bargains. If fair representation were available to guard against minority oppression, then there would be no reason to disallow the judicial enforcement of fines. However, such an approach-the affirmative ordering of the bargain-may disrupt the bargaining process. ${ }^{02}$

If this disruption proves too costly, the Supreme Court could instruct the Board to utilize the duty of fair representation in deciding whether a union should be allowed to secure judicial enforcement of fines. The Board would use the duty of fair representation in a negative manner, allowing union discipline only when the union has not breached its duty of fair representation, and the bargaining process would thus not be directly affected. Such a bar to union discipline might force both the majority and minority to exercise more persuasion and compromise, ${ }^{03}$ and reach bargaining positions which are mutually acceptable. However, such an approach would not protect the minority in those situations in which a strong majority does not need judicial enforcement of fines to drive an unfair bargain.

The factual situation in Scofield $v$. NLRB may be used to illustrate the operation of this approach. The Court found no $8(\mathrm{~b})(1)(\mathrm{A})$ violation where the union secured judicial enforcement of fines upon members who exceeded production ceilings and chose not to bank the excess for future withdrawals when production was less than the ceiling. ${ }^{\text {of }}$ The union had bargained with the company over these ceilings and adjusted them in the process. ${ }^{\circ 5}$ Such union rules relating to the imposi-

61. For a general discussion of the desirability of lodging the duty solely in tha Board, see Wellington, supra note 2, at 168-75. For a strident objection, sce Note, Unfair Rep. resentation as an Unfair Labor Practice, 63 MicH. L. REv. 1081 (1965).

If the Board utilized $8(\mathrm{~b})(1)(\mathrm{A})$ as the primary standard to develop the duty of falr representation, see note 24 supra, it could fashion a duty consistent with judicial enforcc. ment of fines.

62. For example, employers might find it to their bargaining advantage to charge that the union breached its duty of fair representation.

63. It would seem that since many collective bargaining decisions are in a sense highly "political" in nature, such a bar to union discipline might well reintroduce an atmosphere conducive to mutual concession. While certainly less attractive than a liypothetical "costless" duty of fair representation, it may be the best of those which can actuatly be developed. Again, such a restraint on union discipline may still not result in a fitlrer distribution of benefits from a basically oligarchical organization if the minority of workers is very small or without economic power.

64. 394 U.S. at $424-25$.

65. Id. at 426 . 
tion of fines for exceeding production ceilings, while not an actual contract term, clearly furthered the collective bargaining interests of the union. To find an $8(\mathrm{~b})(1)(\mathrm{A})$ violation in such circumstances would allow individual workers to undercut the contract ${ }^{\mathrm{DO}}$-clearly contrary to the thrust of the J.I. Case doctrine. ${ }^{07}$ But focusing on member activities which contravene the intermeshed contract terms and union rules rather than focusing on the earlier negotiation stage may be misleading. The Board should answer the question whether the union was fairly representing the more efficient workers when it wrote these interrelated items into the contract. ${ }^{.8}$

Scofield did attempt in a roundabout fashion to analyze the fairness of the rules. Formulating a dual approach to justify the rule, the Court examined whether the rule served legitimate union interests ${ }^{63}$ and whether it violated any federal labor policy.70 Legitimacy of union interests was found in the historical union concern with overly zealous workers causing breakdowns in piece-rates. ${ }^{11}$ The Court then catalogued the federal policy and found no violation. ${ }^{72}$ As for the duty

66. Although the employer paid workers for excess production, such p3yment is not inconsistent with the assertion that the emplojer took the contract in light of the union rules. The emplojer certainly recognized, even acquiesced in, the deterrent effects of these fines.

67. J.I. Case Co. v. NLRB, 321 U.S. 332 (1944). "Individual bargaining is struck down because such bargaining is often earned at the cost of breaking down some other standard thought to be for the welfare of the group, and always creates the suspicion of being paid at the long-range expense of the group as a whole." 321 U.S. at 338-39.

68. There seem to be two questions involved in this inquiry. Was the union unduly catering to the less efficient workers? Second, were the basic machine rates fairly set?

In Associated Home Builders of Greater East Bay, Inc. y. NLRB, 352 F.2d 745 (9th Cir. 1965 ), the court of appeals upheld a finding that the union violated $8(b)(1)(A)$ by applying dues to fines assessed against members exceeding unilaterally imposed production ceilings. The court remanded, however, to see whether the union committed an unfair labor practice in failing to bargain with the company over these ceilings. Perhaps a more fundamental question for the workers was whether the duty of fiir representation was breached by the union.

69. 394 U.S. at 430 .

70. Id.

71. Id. at 431. As Justice White noted:

[U]nion opposition to unlimited piecework pay systems is historic Union apprehen-

sion, not without foundation, is that such systems will drive up employee productivity and in turn create pressures to lower the piecework rate so that at the new higher level of output employees are earning little more than they did before. The fear is that the competitive pressure generated will endanger workers' health, foment jealousies, and reduce the work force.

Studies of non-union plants suggest that unorganized workers often excrt social pressures to force overzealous workers to restrict output. See Mathewson, Restriction of Oulput Among Unorganized Workets, in Feathersedding and Technological Change (P. Wainstein ed. 1966). In a sense, one could consider these expressions of community attitudes as the purest form of Professor Wellington's community expectation standard. On the other hand, perhaps the community expectation of the plant workers, in some situations, an be altered by the introduction of collective bargaining. Collective bargaining might result in a greater diffusion of information or perhaps perform an cducative function altcring the expectation of the workers.

72. "The union rule left the collective bargaining process unimpaired, breached no 
of fair representation, the Court declared: "All members of the bar. gaining unit, however, have the same contractual rights. In dealing with the employer as bargaining agent the union has accorded all employees uniform treatment." 73 Apparently such uniformity of treatment represented "no dereliction by the union of its duty of fair representation." 74 Uniformity of treatment may constitute fair representation, but the two are not equivalent. ${ }^{.5}$ If the basic machine rates are unfairly set, then uniform production ceilings are not fair. In any event, it is im. portant that the Court recognize that its analysis of the legitimacy of union interests may often approximate an inquiry into an expanded duty of fair representation..$^{76}$

The Board and the courts have yet to face the problem of fashioning a workable standard of fairness. In the absence of any other informing guides, Professor Wellington suggests the standard of community expectations:

Since a particular employee may be unreasonable, single expectations are not in themselves important in creating standards. There is, however, a sense of the employee community on these questions which is significant for decision-making. . . .

The expectations of the employee community may vary with the nature of the interest at stake. ${ }^{77}$

It is doubtful that the Board or the courts can discern community ex. pectations, especially in multi-plant or employer bargaining. It can utilize the past contract to define previous and present expectations, ${ }^{78}$ but in determining the expectations created the adjudicator might well be led back to the decision-making process which enacted these policies

collective contract, required no pay for unperformed services, induced no cliscrimination by the employer against any class of employees, and represents no dereliction by the union of its duty of fair representation." 394 U.S. at 436.

73. Id. at 435 .

74. Id. at 436 .

75. "Indeed, some distinctions are essential. No one would suggest, for example, that wage differentials between skilled and unskilled workers necessarily violates tha union's duty of fair representation. To the contrary, a failure to discriminate would be a breach of [the] duty." Wellington, supra note 2, at 156.

76. See infra.

77. Wellington, supra note 2 , at $\mathbf{1 6 4 \cdot 6 5}$.

Professor Blumrosen seems to reject the need to protect generalized expectutions: The basic distinction between negotiation and administration lies in the fitct that the individual employee's claim in the latter area is rooted in a collective bargaining agreement, while in the former case his claim rests on generalized expectations. 'The refusal to protect generalized expectations need not lead to a refusal to protect specific claims under specific contracts.

Blumrosen, The Worker and Three Phases of Unionism: Administrative and Julicial

Control of the Worker-Union Relationship, 61 MrcH. L. REv. 1435, 1476 (1968).

78. Wellington, supra note 2 , at 164 . 
into contractual form. This inquiry will seldom yield any clear answers.

The courts and the Board should articulate a more sensitive duty of fair representation either as an affirmative union duty or as a defense to judicial enforcement of union fines. But if the standard of fairness is illusory and the duty of fair representation, therefore, unworkable, the Allis-Chalmers rule has provided union majorities with increased coercive power. This power can be used either to bridle minority dissent or to prevent opportunistic strikebreaking. The Court may decide that the risk of majoritarian oppression is less great and less worrisome than the dangers of strikebreaking opportunism. But until the search for a standard of fairness proves fruitless, the courts and the Board should attempt to fashion a sensitive duty of fair representation which offers protection against the misuse of judicially enforced fines. 